\title{
Comparison of the Nuclear DNA Stability against Freezing-Thawing and High Temperature Treatments between Spermatozoa and Somatic Cells
}

\author{
Seiichiroh OHSAKO, Reiko NAGANO'1), Yasushi SUGIMOTO2), and Kazufumi GOTO') \\ Laboratories of Veterinary Anatomy, ${ }^{11}$ Animal Reproduction, and ${ }^{2)}$ Animal Biochemistry and Food Science, Faculty of Agriculture, \\ Kagoshima University, 1-21-24 Kohrimoto, Kagoshima 890, Japan \\ (Received 27 February 1997/Accepted 27 June 1997)
}

ABSTRACT. Thermostability of sperm genome against freezing-thawing and high temperature treatments was assessed by comparing the degradation patterns of genomic DNAs from epididymal sperms and somatic tissues. Golden hamster liver, kidney, epididymal sperm, and testis were frozen and thawed repeatedly, or incubated in a hot water bath. Genomic DNAs were isolated and then separated by agarose gel electrophoresis. It was revealed that the size of sperm genomic DNA was hardly changed after freezing-thawing treatment, however, the DNA sizes of the other three tissues were gradually reduced with an increasing number of freezing-thawing cycles. In contrast, high temperature treatment appears to damage not only the genomic DNAs of somatic cells but also those of spermatozoa. - KEY WORDS: DNA, sperm, temperature.

J. Vet. Med.Sci. 59(11): 1085-1088, 1997

Mammalian sperm DNA is the most tightly compacted eukaryotic DNA, being at least six-fold more highly condensed than the DNA in mitotic chromosomes [17]. This feature is due to the dramatic restructuring of chromatin during spermiogenesis, where some spermatogenic cell specific nuclear proteins, i.e., protamine and transition protein, are expressed instead of the histones [1, 3, 11]. The whole DNA of sperm is, therefore, believed to be very resistant to various environmental, physical and chemical insults, for example, exposure to high temperature and freezing-thawing $[9,12,19]$.

A recent advanced assisted reproductive technique, intracytoplasmic sperm injection (ICSI), has demonstrated that killed sperm or only sperm heads separated from tails were still useful for making normal offspring $[2,10]$. The fact that the sperm nucleus is capable of fertilization regardless of whether it is dead or alive gives us an exciting suggestion for a strategy to rescue endangered or already extinct animals. If dead spermatozoa from male corpses are available, ICSI can resuscitate the dead cell whole genome in recipient eggs. This raises the question of what level of damage can be sustained by sperm DNA without seriously affecting fertilization. There is, however, no precise study about the relationship between the damage of nuclear DNA of condensed sperm heads and fertilization completion or normal development of embryos. Moreover, there are only a few reports comparing the nuclear DNA stability against environmental insults between spermatozoa and somatic cells [13]. So we do not have enough information about the resistance of sperm DNA against various environmental stresses. In the course of this study, we therefore conducted an experiment to compare the differences of resistance between sperm and somatic cell DNAs against freezingthawing and high temperature treatments by examining the changes of extracted genomic DNAs after each treatment.

Two male golden hamsters maintained as a closed colony in our laboratory were sacrificed under diethyl-ether anesthesia and four pieces of liver, kidney, caudal epididymides, and testes were removed. To examine the effects of freezing-thawing treatments, they were all put in sterile polypropylene tubes after washing with phosphate buffered saline (PBS), and divided into four groups. One group was kept in a freezer at $-20^{\circ} \mathrm{C}$ quickly, and the other three groups were frozen in liquid nitrogen, and then thawed by 10 min incubation in a shaking water bath at $27^{\circ} \mathrm{C}$. This freezing-thawing cycle was repeated 5 , 10 , or 20 times and each sample was then kept in a freezer at $20^{\circ} \mathrm{C}$ until genomic DNA isolation. Sperms were collected by partially cutting caudal epididymis in TBS solution (10 $\mathrm{mM}$ Tris- $\mathrm{HCl}, 150 \mathrm{mM} \mathrm{NaCl}, \mathrm{pH}$ 7.4). An approximate 0.1 $\mathrm{m} l$ volume of sperm pellet and all the other tissue homogenates were resuspended with $1.4 \mathrm{ml}$ lysis buffer containing $150 \mathrm{mM} \mathrm{NaCl}, 15 \mathrm{mM}$ Sodium acetate, $1 \mathrm{mM}$ EDTA, $1 \%$ SDS, $0.01 \mathrm{mg} / \mathrm{m} l$ Proteinase K (Nacalai Tesque, Inc., Tokyo, Japan), and then incubated in a shaking water bath at $50^{\circ} \mathrm{C}$ for $1 \mathrm{hr}$. In order to remove nuclear basic proteins, $167 \mu l$ of $1 \mathrm{M}$ 2-mercaptoethanol (Nacalai Tesque, Inc. Tokyo, Japan) was added followed by $3 \mathrm{hr}$ incubation. After a two-fold phenol extraction, they were digested with $100 \mu \mathrm{g} / \mathrm{m} l$ RNase A (Sigma, MO, U.S.A.) at $37^{\circ} \mathrm{C}$ for $1 \mathrm{hr}$. After phenol/chloroform extraction and ethanol precipitation, DNAs were resuspended in TE (10 mM Tris, $1 \mathrm{mM}$ EDTA, pH 8.2), and their concentration was then measured by UV spectrophotometer. All the isolated DNA samples were evenly separated by $0.8 \%$ agarose gel electrophoresis and observed with a UV transilluminator. With the same protocol, the same tissues were frozen at $-80^{\circ} \mathrm{C}$ in a deep freezer or at $-20^{\circ} \mathrm{C}$ in a freezer for $1 \mathrm{hr}$ and thawed at $27^{\circ} \mathrm{C}$ in a shaking water bath. The cycle was repeated 5,10 , or 20 times and the samples were then kept at $-20^{\circ} \mathrm{C}$ in a freezer until DNA isolation. Additionally, to examine effects of high temperature treatment, one set of tissues was incubated at $50^{\circ} \mathrm{C}$ in a hot shaking water bath for $30 \mathrm{~min}, 1 \mathrm{hr}, 3 \mathrm{hr}$, and $6 \mathrm{hr}$, respectively, and then kept at $-20^{\circ} \mathrm{C}$ in a freezer until DNA isolation.

In the experiments of freezing-thawing treatment, the core DNA sizes of isolated genomic DNAs from liver, kidney and testis on the gels, approximately $100 \mathrm{~kb}$, were reduced 


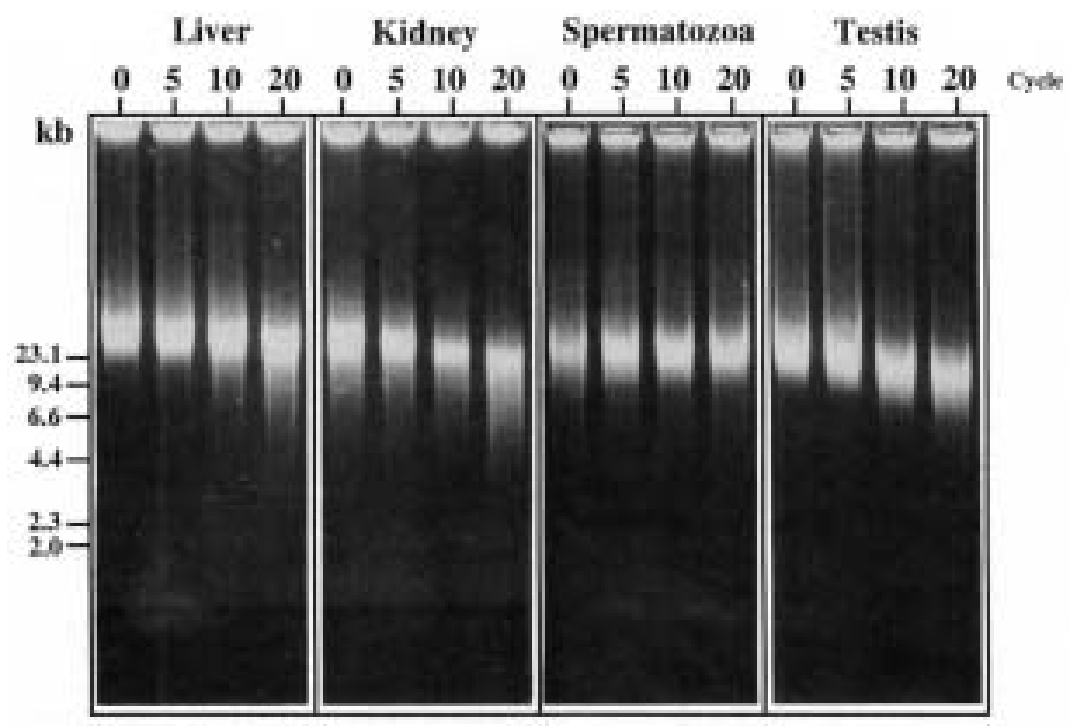

Fig. 1. Effect of freezing-thawing treatment on genomic DNAs of hamster liver, kidney, epididymal sperm, and testis. Golden hamster liver, kidney, caudal epididymis, and testis were frozen in liquid nitrogen and then thawed. The freezingthawing cycles were repeated 5, 10 or 20 times, then genomic DNAs were isolated and separated on $0.8 \%$ agarose gels $(1 \mu g / l a n e)$. Note the reductions of core DNA sizes of liver, kidney and testis with the increasing number of freezing-thawing cycles, whereas there is no effect on epididymal sperms. Numbers of the lanes indicate cycles of freezing-thawing treatment. DNA size markers are indicated on the left.

with an increasing number of freezing-thawing cycles of each tissue (Fig. 1). After 20 cycles of freezing-thawing, the size of core DNAs was reduced to about $50 \mathrm{~kb}$ in liver and testis, and to about $20 \mathrm{~kb}$ in kidney. In liver and kidney, band smearing by smaller DNA fragments was much more evident after 20 cycles when compared with 5 or 10 cycles of freezing-thawing. In epididymal sperms, the $100-\mathrm{kb}$ core DNA size did not change even after 20 cycles of freezingthawing. Moreover, smearing of the DNA bands was not observed at all. The same result was obtained after treatments of each sample at $-20^{\circ} \mathrm{C}$ or $-80^{\circ} \mathrm{C}$ (data not shown).

In the experiment of high-temperature treatment, the core DNA sizes of isolated genomic DNAs from liver, kidney and testis on the gels were reduced with an increase in the heating period (Fig. 2). In $6 \mathrm{hr}$ treatment, clear DNA band smearing was observed in all the three tissues, especially in kidney. In epididymal spermatozoa, while smearing of the DNA bands was observed with an increase of heating period, the core DNA size did not change after any heating period. We observed much higher degradation in $60^{\circ} \mathrm{C}$ and $70^{\circ} \mathrm{C}$ treatments of all these tissues (data not shown).

In the present study, we isolated genomic DNAs using 2mercaptoethanol as a reducing reagent. By this method, most of the nucleoproteins, which are tightly bound to DNA, like protamine, can be removed, and nucleic acids are extracted into an aqueous phase about 50 times more easily than by the normal extraction protocol described by Sambrook et al. [15]. We also used RNase A to remove high molecular weight RNA molecules, and all the remaining molecules containing both intact and fragmented DNAs were directly precipitated with ethanol without dialysis. So the relatively intact DNAs and fragmented DNAs were visualized as a core DNA band and as a smear, respectively. This treatment is a rather rough one but the core DNA bands from fresh tissues, expected to be an approximate size of $100 \mathrm{~kb}$, could be observed on the gels by our routine Southern blotting procedure. Although the size of the core DNA band varied with tissue samples, our procedure clearly represented the gradual degradation process of genomic DNAs by a smear below the core bands, which did not occur during the isolation procedure.

The core DNA bands on the gels were thought to be derived from the DNAs packaged in the core structures of chromosomes or nuclei which are resistant to peripheral stresses. In the somatic cells, the core DNA sizes reduced with an increasing number of freezing-thawing cycles, however, band smearing was only observed after 20 cycles, and was much less pronounced than in the high temperature treatment. This observation, therefore, suggested that fragmentation of genomic DNAs during freezing-thawing treatment might occur at a specific DNA region highly sensitive to freezing-thawing, which is not in the core structure described above. In high temperature treatment, additional non-specific fragmentation might occur in the core structures. In contrast, the size of the core DNA of sperm samples did not change, but band smearing was observed in high temperature treatment, suggesting that only non-specific fragmentation might occur in the whole DNA region, or that sperm does not have such a putative core 


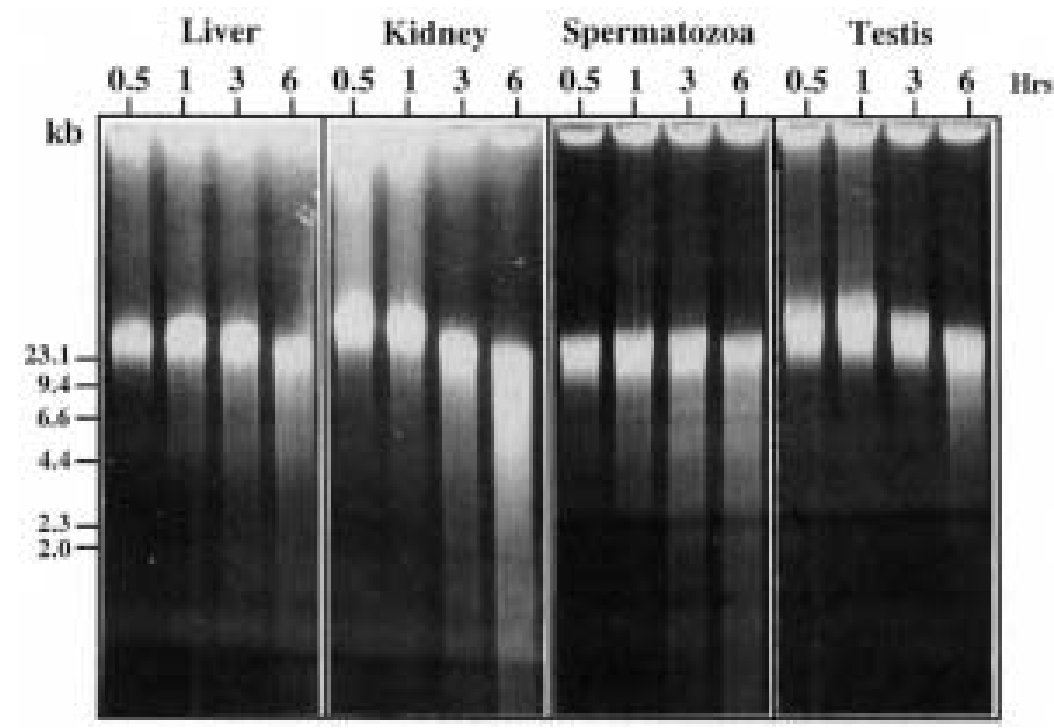

Fig. 2. Effect of high temperature treatment on genomic DNAs of hamster liver, kidney, epididymal sperm, and testis. Golden hamster liver, kidney, caudal epididymis, and testis were incubated at $50^{\circ} \mathrm{C}$ in a water bath for $30 \mathrm{~min}, 1 \mathrm{hr}, 3 \mathrm{hr}, 6$ hr. Genomic DNAs were isolated and separated on $0.8 \%$ agarose gels $(1 \mu \mathrm{g} / \mathrm{lane})$. Note the DNA band smear of all samples with the increasing length of the heating period. Numbers of the lanes indicate hours of heating. DNA size markers are indicated on the left.

structure as in somatic cells.

Millions of normal calves are born by artificial insemination using cryopreserved spermatozoa [18], and Iritani and Nishikawa [8] observed no change in the pregnancy rate of cows inseminated with spermatozoa frozen for 25 years compared with fresh spermatozoa from the same bull. Uehara and Yanagimachi [16] and Yanagida et al. [19] reported that the nuclei of mature hamsters and human spermatozoa remained capable of developing into pronuclei after they had been frozen or freeze-dried when they were injected into oocytes. The pronuclei which developed from the freeze-dried nuclei could synthesize DNA [9]. Furthermore, normal offspring were born after intracytoplasmic injection of spermatozoa killed by freezingthawing without a cryoprotectant in bovine [2], sawflies [5] and humans [7]. Although nuclear DNA of some spermatozoa may be damaged by freezing-thawing as reported by several other groups [4, 13, 14], the numerous reports above suggested genomic DNA of the majority of spermatozoa will not be damaged by freezing and thawing. Our present data clearly demonstrated that genomic DNAs of spermatozoa are very resistant to freezing and thawing treatment compared with somatic cells.

In contrast to the resistance to freezing and thawing treatment, the stability of sperm DNA to high temperature treatment was revealed to be as poor as somatic DNA in the present study. This finding is novel and surprising because Yanagida et al. [19] demonstrated that a considerable proportion of hamster, mouse and human sperm nuclei developed into pronuclei even after $30 \mathrm{~min}$ treatment at $90^{\circ} \mathrm{C}$ when they were injected into hamster oocytes.
Furthermore, Hoshi et al. [6] reported that $16 \%$ of rabbit oocytes injected by heat-treated $\left(60^{\circ} \mathrm{C}, 30 \mathrm{~min}\right)$ rabbit sperm developed to the 6- to 8-cell stage. These reports in conjunction with our present result appear to suggest that sperm nuclei may develop into pronuclei even after their DNAs have been damaged. Further research is needed to clearify this interesting point.

In summary, our results suggest that sperm genomic DNA is extremely resistant to freezing-thawing treatment but somatic cell DNA has a poor resistance. High temperature treatment appears to damage not only the genomic DNAs of somatic cells but also those of spermatozoa. The result rationalizes the cryopreservation (without cryoprotectant) of dead male animals, because the genomic DNAs of spermatozoa remained intact after freezing-thawing treatment.

\section{REFERENCES}

1. Bedford, J. M. and Clavin, H. I. 1974. J. Exp. Zool. 188: 137-155.

2. Goto, K., Kinoshita, A., Takuma, Y., and Ogawa, K. 1990. Vet. Rec. 127: 517-520.

3. Green, G. R., Balhorn, R., Poccia, D. L., and Hecht, N. B. 1994. Mol. Reprod. Dev. 37: 255-263.

4. Hamamah, S., Royere, D., Nicolle, J. C., Paquignon, M., and Lansac, J. 1990. Reprod. Nutr. Dev. 30: 59-64.

5. Hatakeyama, M., Sawa, M., and Oishi, K. 1994. J. Insect Physiol. 40: 909-912.

6. Hoshi, K., Yazawa, H., Yanagida, K., and Sato, A. 1992. Arch. Androl. 29: 233-237.

7. Hoshi, K., Yanagida, K., Yazawa, H., Katayose, H., and Sato, 
A. 1994. J. Assisted Reprod. Genet. 11: 325-326.

8. Iritani, A. and Nishikawa, Y. 1992. pp. 302-309. In: Spermatology (Mohri, H., Morisawa, M., and Hoshi, K. eds.), University of Tokyo Press, Tokyo (in Japanese).

9. Katayose, H., Matsuda, J., and Yanagimachi, R. 1992. Biol. Reprod. 47: 277-284.

10. Kimura, Y. and Yanagimachi, R. 1995 Development 121: 2397-2405.

11. Marushige, Y. and Marushige, K. 1974. Biochim. Biophys. Acta 340: 498-508.

12. Meistrich, M.L., Reid, B. O., and Barcellona, W. J. 1979. Exp. Cell Res. 99: 72-78.

13. Royere, D., Hamamah, S., Nicolle, J. C., Barthelemy, C., and Lansac, J. 1988. Gamete Res. 21: 51-57.
14. Royere, D., Hamamah, S., Nicolle, J. C., and Lansac, J. 1991. Int. J. Androl. 14: 328-332.

15. Sambrook, J., Fritsch, E. F., and Maniatis, T. 1989. In: Molecular Cloning A Laboratory Manual, 2nd ed., Cold Spring Harbor Laboratory Press, New York.

16. Uehara, T. and Yanagimachi, R. 1976. Biol. Reprod. 15: 467470.

17. Ward, S. D. and Coffey, D. S. 1991. Biol. Reprod. 44: 569574.

18. Watson, P. F. 1990. pp. 747-869. In: Marshall's Physiology of Reproduction, vol.2 (Lamming, G. E. ed.), Churchhill Livingstone, Edinburgh.

19. Yanagida, K., Yanagimachi, R., Perrault, S. D., and Kleinfeld, R. G. 1991. Biol. Reprod. 44: 440-447. 